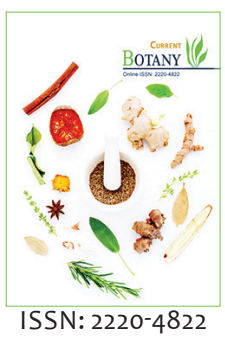

Received: January 16, 2020

Revised: July 14, 2020

Accepted: July 20, 2020

Published: July 28, 2020

*Corresponding Author:

Bokary Allaye Kelly

E-mail: bokarykelly@gmail.com KEYWORDS: Climatic gradient, field, fallow, parkia biglobosa, sanitary constraints, southern-mali

\section{Parkia biglobosa (Nere)-A threatened useful tree species: Directory of sanitary constraints according to north-south climatic gradient in Mali}

\author{
Bokary Allaye Kelly*, Amadou Malé Kouyaté \\ Institut d'Economie Rurale, Programme Ressources Forestières, Centre Régional de la Recherche Agronomique de \\ Sikasso, BP 178 Sikasso, Mali
}

\begin{abstract}
Parkia biglobosa, a multi-purposes species offers food, medicine and income to rural populations. This species is facing several constraints mainly aged populations, weak natural regeneration, and reduction of tree densities. A study, was undertaken in three sites from three agro-climatic zones according to the north-south climatic gradient in southern Mali, to assess dendrometric characteristics of Parkia biglobosa trees. Permanent plots of 0.25 ha each were installed in fields and fallows with three replications in each stand within each site. Adult trees in the plots were monitored, measured and also assessed for sanitary constraints. Several sanitary constraints were encountered and classified into six categories (from attacks on trunks and gross branches to damages on fruits and general attacks, infestations and damages due to wood-boring insects, human beings and other abiotic factors). Damages like those with symptoms of dieback or staghead disease pose a serious threat for production, productivity and survival of the species. Concrete actions are necessary like sanitary diagnostic at the level of the distribution area of the species in Mali, followed by identifying real cause of damages and seeking for appropriate solutions, sensitizing and training farmers, implementing a national program of regeneration of the species by planting and/or by promoting Assisted Natural Regeneration (ANR) approach.
\end{abstract}

\section{INTRODUCTION}

\section{Parkia Biglobosa (African Locust Bean / Néré)}

From the family of Leguminosae/Fabaceae, Parkia biglobosa is a forest tree species frequent in agroforestry parklands of the sudanian and sudano-guinean savannah. The species is present in up to 20 African countries from Senegal in the West to Uganda in the East [1]. It is a useful multi-purposes tree species in Sub-Saharan Africa [2], offering food, medicine, and income to rural population and contributing to fight poverty [3]. The main product of this species called "soumbala" or "dawadawa", produced from fermented seeds, is a particularly appreciated and widely used spice in Africa, rich in proteins and containing lipids, essential amino acids, essential fatty acids, vitamins and mineral compounds $[4,5,6]$.

This useful tree species, is nowadays, facing several constraints such as the aged populations, the weak natural regeneration, the regression of the natural area and the reduction of tree densities $[7,8]$. Hence, a study funded by Malian Government in the frame of the "Competitive Funds for Research and Technological Innovation" (CFRTI), was conducted to assess dendrometric characteristics and sanitary constraints of Parkia biglobosa populations in fields and fallows in southern Mali. The present communication is a directory of sanitary constraints affecting Parkia biglobosa trees in study area along the northsouth climatic gradient.

\section{MATERIAL AND METHODS}

The vegetal material is formed of adult Parkia biglobosa trees. The study was undertaken in three sites belonging to three agroclimatic zones according to the north-south climatic gradient (Figure 1). The sites were Somasso in the north sudanian zone (district of Bla), Zanzoni in the south sudanian zone (district of Koutiala) and Diou in the north Guinean zone (district of Kadiolo). Figure 1 shows the three study zones (districts) in green and Figure 2 shows sites localization in the respective districts.

In each site, permanent plots of $50 \mathrm{~m} \times 50 \mathrm{~m}=2500 \mathrm{~m}^{2}$ ( $0.25 \mathrm{ha}$ ) were installed in two types of stand (field and fallow). 
For each stand there were three replications giving a total of eighteen populations of Parkia biglobosa (3 sites x 2 stands $\mathrm{x} 3$ replications $=18$ populations). In each plot, five adult $P$. biglobosa trees were marked with yellow paint, referenced using GPS GARMIN eTrex 10 (precision $\pm 3 \mathrm{~m}$ ). The sample size was therefore fifteen trees by stand $(5$ trees $\times 3$ replications $=15$ trees) giving thirty trees by site ( 15 trees $\times 2$ stands $=30$ trees) and a total of ninety trees for the three sites ( 30 trees $\mathrm{x} 3$ sites $=90$ trees). These adult P. biglobosa, trees were measured and observed for sanitary damages.

The measured variables were: the diameter at $1,30 \mathrm{~m}$ above the ground (DBH) using forestry compass, the total height (TH) using graduated ruler of $12 \mathrm{~m}$, the mean crown diameter (MCD) from measurements of the crown diameter according to the north-south and east-west directions using measuring tape of $30 \mathrm{~m}$. Observed damages concerned infestations, attacks, desiccations break and cuts. These damages were categorized as sanitary constraints and each category include up to three or four types of damages.

The infestation rate was estimated by site based on the number of individuals trees affected by at least one category of constraints relative to the total number of monitored trees in the site. The prevalence of each category of constraint was also estimated by site based on the number of cases i.e. the number of trees affected by the category of constraint in a given site relative to the total number of monitored trees in the site.

\section{RESULTS}

\section{Recorded Damages}

Various constraints were encountered and classified into six categories. The six categories were illustrated by images as shown below:
- Category 1: attacks on trunks and gross branches consisting of splits, cavities, moulds and peeling (Figure 3).

- Category 2: attacks and damages on branches and tree crowns' consisting of breaks, symptoms of dieback or staghead disease and fungi (Figure 4).

- Category 3: damages caused by wood-boring insects consisting of perforation and oozing (Figure 5).

- Category 4: damages caused by human being consisting of craft wood exploitation and pruning to reduce concurrence with crops (Figure 6).

- Category 5: generalized attacks of trees by termites, ants (causing necrosis) and infestation by lianas and Tapinanthus (Figure 7).

- Category 6: fruit damages caused by predators, mainly parrots (Figure 8).

\section{Level of Infestation of P. biglobosa Trees}

The number of infested P. biglobosa trees by site and stand was shown in Table 1. For all sites and stands together, the global infestation rate was $89 \%$. For all sites together, infestation rates were $93 \%$ in fallow stand and $80 \%$ in field stand and for all stands together, infestation rates were $100 \%$ at Somasso and Zanzoni and $67 \%$ at Diou. Regarding stands within site, at Somasso and Zanzoni, $100 \%$ of trees in field and fallow stands were infested whereas at Diou, the number of infested trees was higher in fallow stand (93\%) compared to field stand (40\%).

\section{Prevalence of Constraint Categories}

The prevalence of constraints categories in the different sites was shown in Table 2. Prevalence of constraint categories varied according to sites. Five categories were observed in all sites; category 3 (damage due to wood-boring insects) being the only category observed in only one site (Somasso,

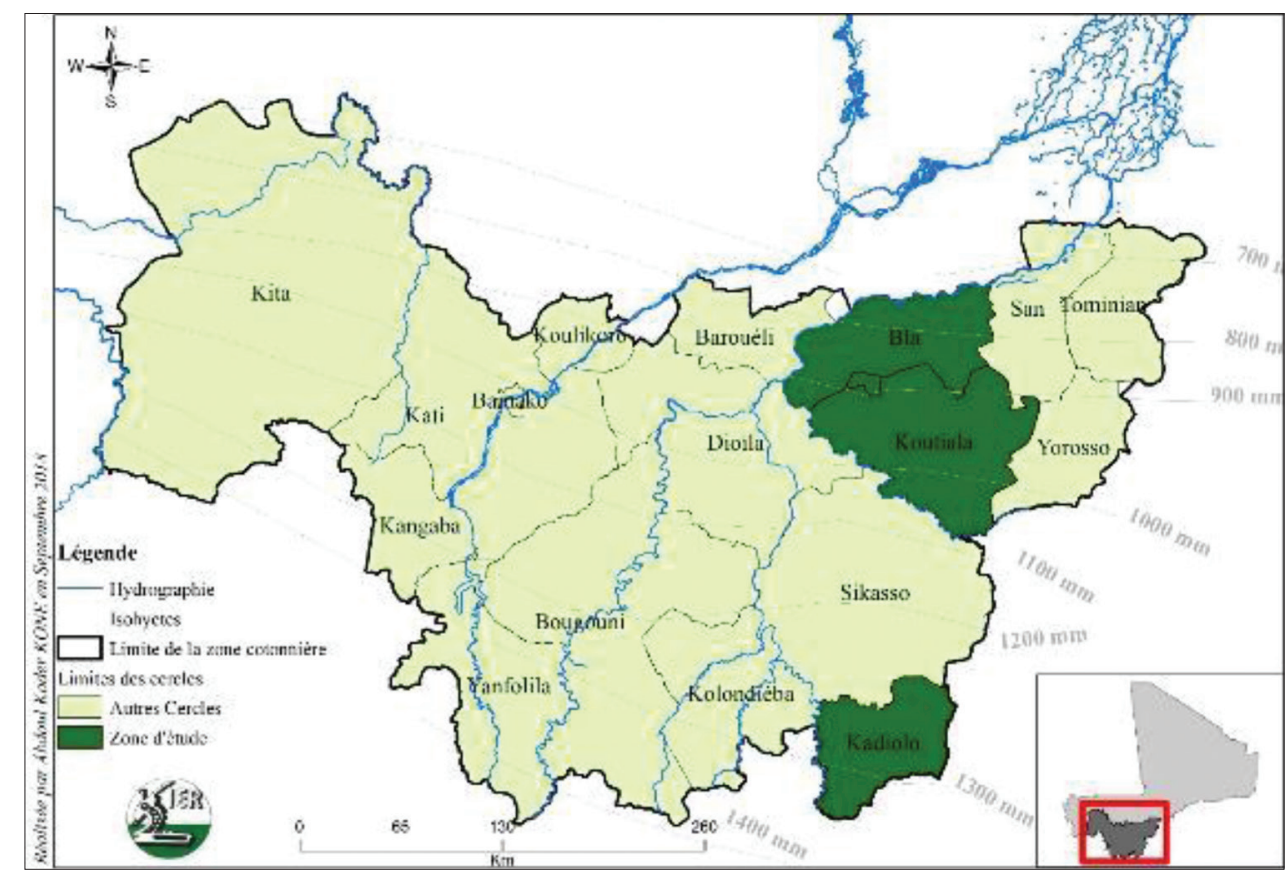

Figure 1: Study zones (green area) 


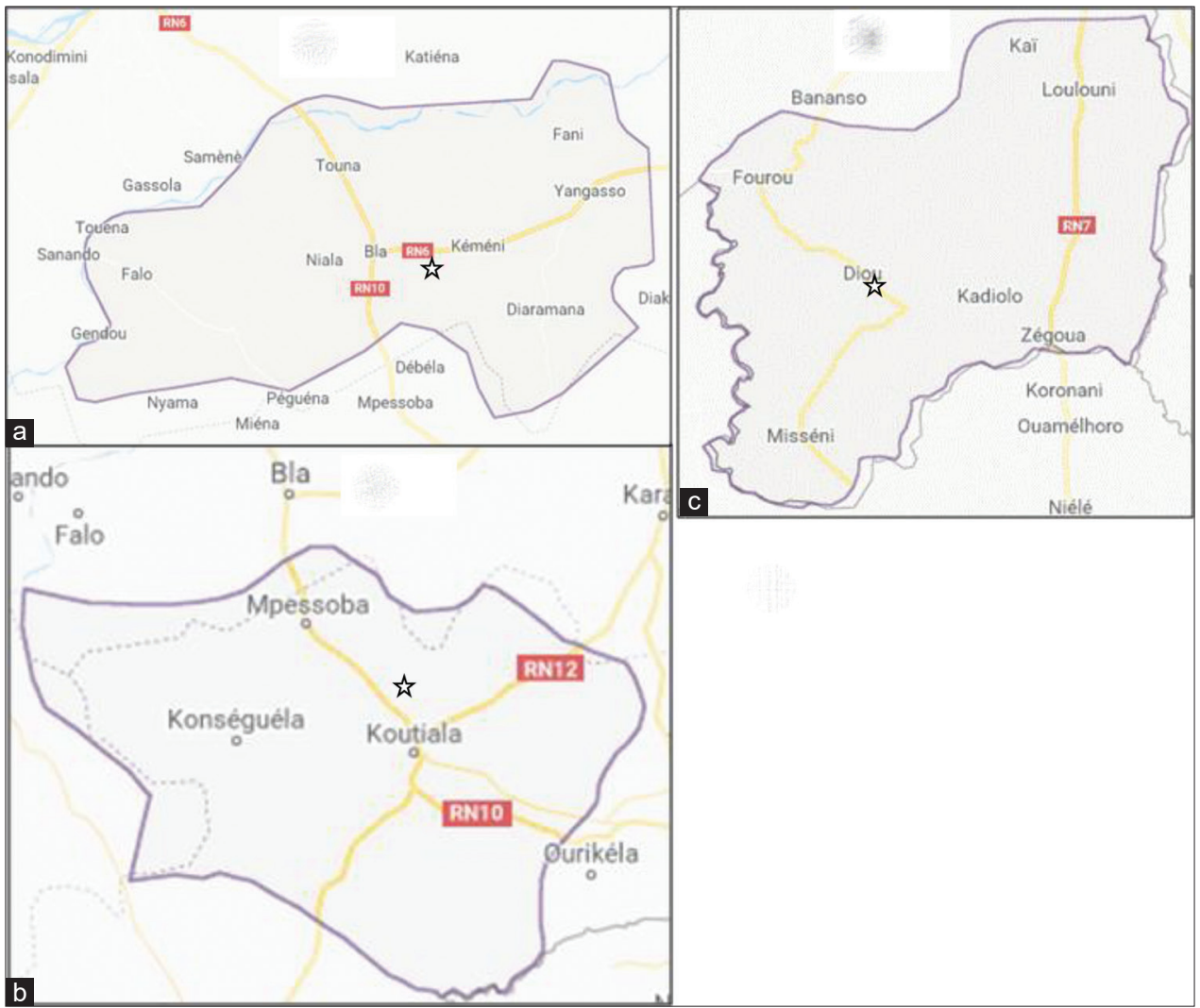

Figure 2: Sites localization in the respective districts indicated by asterisk ( $\vec{k}$ ): $2 \mathrm{a}$ Somasso in the district of Bla, $2 \mathrm{~b}$ Zanzoni in the district of Koutiala and 2c Diou in the district of Kadiolo

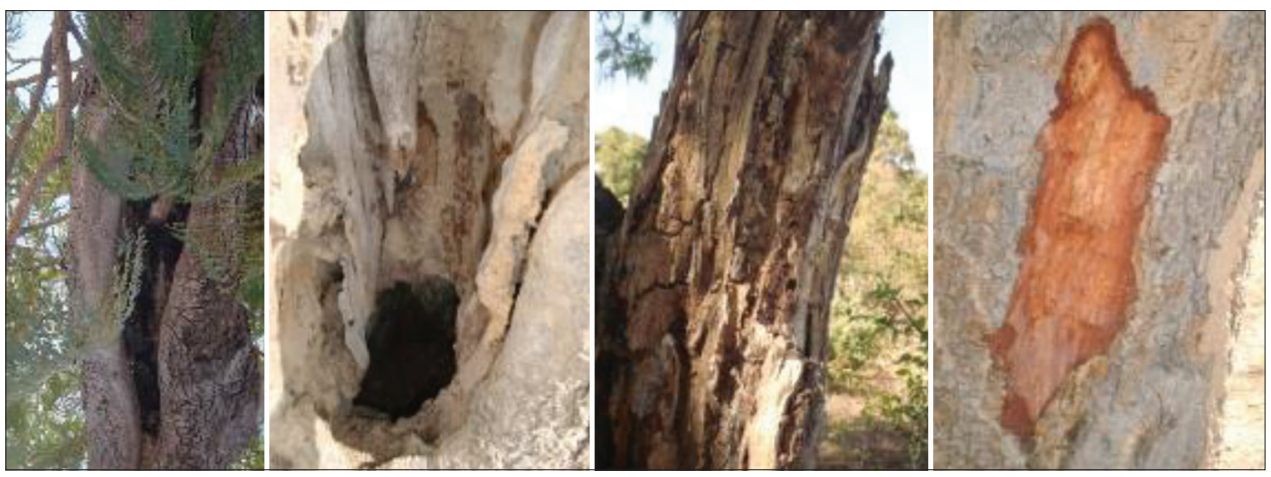

Figure 3: Images of splits, cavities, moulds and peeling on P. biglobosa tree trunks (source: Kelly, 2019)
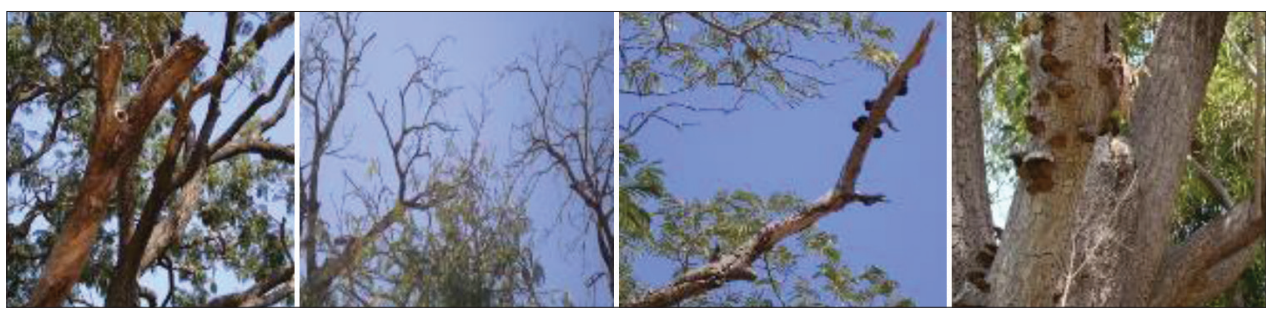

Figure 4: Images of breaks, desiccations and fungi (source: Kelly, 2019)

in the north sudanian zone) with a lowest prevalence $(10 \%)$. Among the five categories observed in all sites, four categories (1, 4, 5 and 6) displayed a decreasing prevalence from the north sudanian to the north Guinean (Tableau 2) and category 2 (attacks and damages on branches and tree crowns') showed a highest prevalence at Zanzoni (south sudanian). The site of Somasso had the highest number of categories with high prevalence (categories 6, 2 and 5 
Table 1: Number of monitored and infested $P$. biglobosa trees by site and stand

\begin{tabular}{|c|c|c|c|c|c|}
\hline \multirow[t]{2}{*}{ Sites (ACZ) } & \multicolumn{2}{|c|}{ Field stand } & \multicolumn{2}{|c|}{ Fallow stand } & \multirow{2}{*}{$\begin{array}{c}\text { Total infested } \\
\text { by site }\end{array}$} \\
\hline & Number of monitored trees & Number of infested trees & Number of monitored trees & Number of infested trees & \\
\hline Somasso (NS) & 15 & 15 & 15 & 15 & 30 \\
\hline Zanzoni (SS) & 15 & 15 & 15 & 15 & 30 \\
\hline Diou (NG) & 15 & 6 & 15 & 14 & 20 \\
\hline Total all sites & 45 & 36 & 45 & 44 & 80 \\
\hline
\end{tabular}

Legend: $A C Z=$ agro-climatic zone, $N S=$ north sudanian, $S S=$ south sudanian, NG=north guinean

Table 2: Prevalence of $P$. biglobosa sanitary constraint categories according sites along the north-south climatic gradient

\begin{tabular}{|c|c|c|c|}
\hline \multirow[t]{2}{*}{ Constraint Categories } & \multicolumn{3}{|c|}{ Prevalence (\%) of constraint categories by site (agro-climatic zone) } \\
\hline & Somasso (NSZ) & Zanzoni (SSZ) & Diou (NGZ) \\
\hline Cl. Attacks on trunks and gross branches & 27 & 10 & 7 \\
\hline C2. Attacks and damages on branches and tree crowns' & 80 & 83 & 40 \\
\hline C3. Damages caused by wood-boring insects & 10 & 0 & 0 \\
\hline C4. Damages caused by human being & 43 & 17 & 10 \\
\hline C5. Generalized attacks of trees by termites, ants, lianas and Tapinanthus & 73 & 67 & 33 \\
\hline C6 Fruit damages caused by predators & 87 & 73 & 27 \\
\hline
\end{tabular}

Legend: $\mathrm{Ci}=$ category $\mathrm{i}(\mathrm{i}=1$ to 6 ), NSZ=north sudanian zone, $\mathrm{SSZ}=$ south sudanian zone, $\mathrm{NGZ}=$ north guinean zone

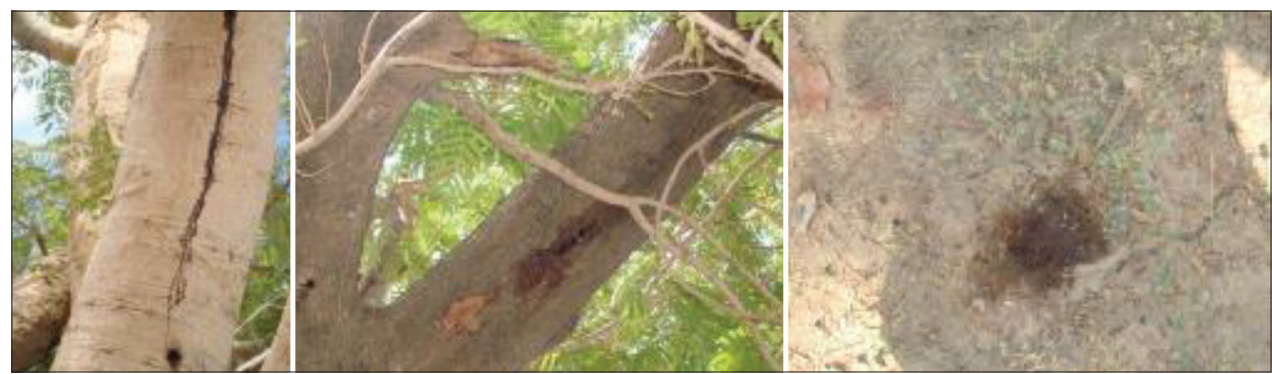

Figure 5: Images of perforation and oozing (source: Kelly, 2019)

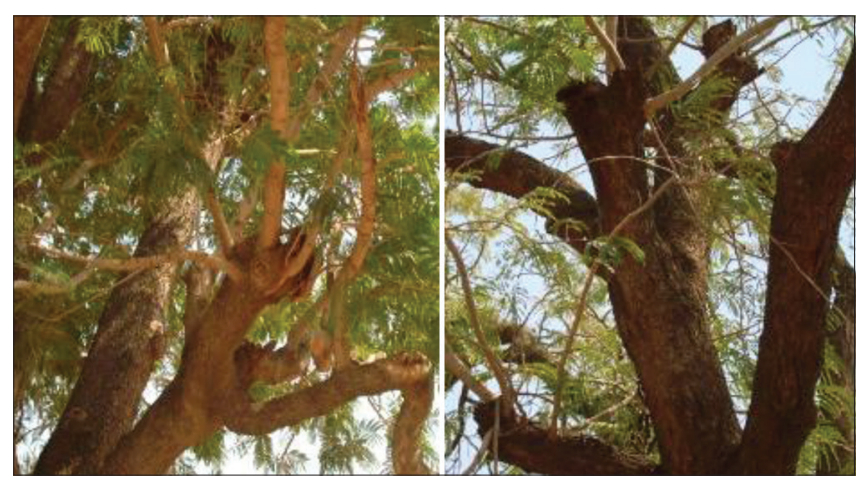

Figure 6: Images of cuts and pruning (source: Kelly, 2019)

with prevalence rates of $87 \%, 80 \%$ and $73 \%$ respectively). These categories are the main constraints in all sites. Two categories (1 and 6) had high prevalence at Zanzoni $(83 \%$ and $73 \%$ respectively).

From table 2, one can observe that the prevalence of sanitary constraints of P. biglobosa displayed an effect of climatic gradient. For instance, more categories with high prevalence were encountered at Somasso (north sudanian), followed by Zanzoni (south sudanian) and finally Diou (north guinean), this last site showing lowest prevalence of all constraints categories.

\section{DISCUSSION}

P. biglobosa is known to suffer several type of attacks. Cattle, insects, termites, bacteria and fungi could cause damages on seedlings, leaves, fruits, pulp and wood [9]. According to Ademola \& Oyum (2016) [9], many bacteria of various genus were identified on soil samples collected under P. biglobosa trees and out of eight studied countries, samples from Mali showed highest rate of fungi colonies. These authors reported also that, bark and leaves of $P$. biglobosa, despite their large use in traditional medicine, are colonized by pathogen fungi like Botryopilodia sp.

In our case, damages with symptoms of dieback and staghead disease (category 2) are the most alarming sanitary constraints encountered. This phenomenon has high prevalence in study sites particularly in the two sites of the sudanian zone, where many trees present symptoms of dieback. According to Encyclopaedia Britannica [10], dieback and staghead are caused by many fungi and few bacteria that produce cankers, anthracnose, wilts etc. and can lead to tree mortality. Nematodes, stem or root-boring insects, mechanical damage, deficiency or excess of moisture, etc., may also cause dieback, directly or indirectly [10].

An effect of the climatic gradient was displayed by the prevalence of constraint categories, highlighting the role of site in P. biglobosa 


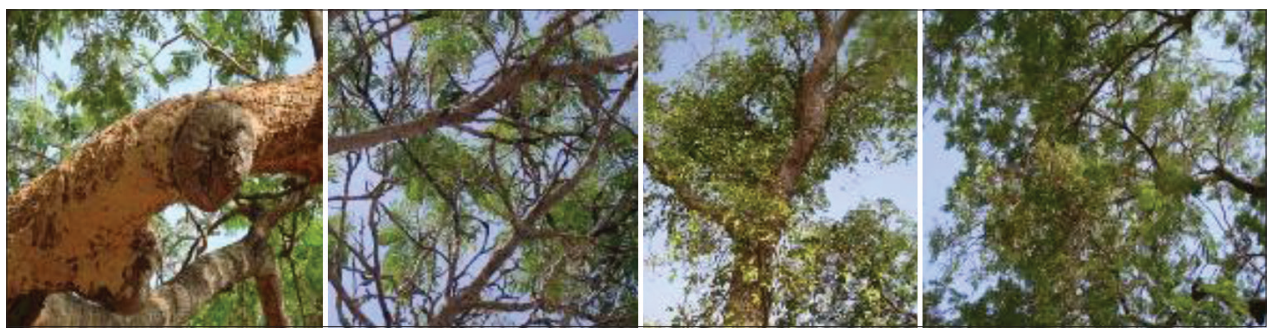

Figure 7: images of attacks by termites, ants and infestation by lianas and Tapinanthus (source: Kelly, 2019)
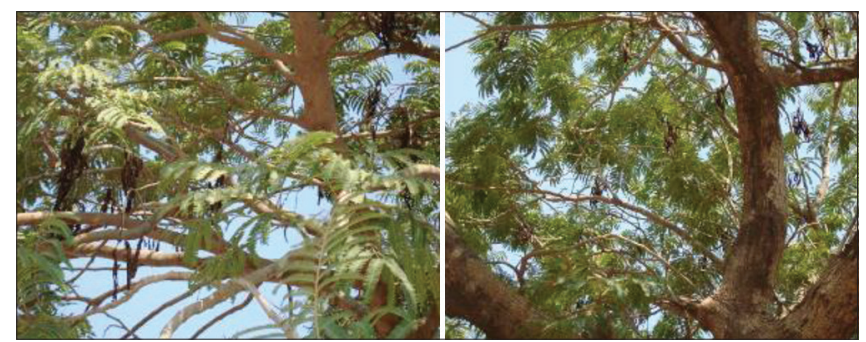

Figure 8: images of damaged fruits hanging on the trees (source: Kelly, 2019)

sanitary constraints. Broadly, the factor site includes many aspects such as climatic aspects like rainfall, temperature, humidity; anthropic aspects like management practices, socio-economic conditions; ecological aspects like soil, relief, toposequence among others. These aspects may cause directly or indirectly sanitary constraints. It was observed that, for the northern site where the climate was dryer and anthropic pressure on poor vegetal resources was high, the prevalence of constraints was also high.

Though previous studies showed that extract from organs of P. biglobosa can fight some pathologies, and despite the number and the prevalence of observed constraints, any action was undertaken to face the sanitary constraints of this tree species at local or national level. For instance, Ojewumi et al. [11] reported that the extracts of $P$. biglobosa seeds have termiticidal effect and can be effectively used to control termite infestation instead of the toxic and environmentally unfriendly chemicals. Olugbemi [12] also reported that extracts from the raw seeds of $P$. biglobosa, exhibited varying degree of termiticidal activity. This author stated that "while extracts from the boiled seed had no effect on the workers of Coptotermes intermedius Silvestri; alcoholic extracts were more active than the aqueous and acetone extracts. Termites die within $30 \mathrm{~min}, 40 \mathrm{~min}$, and 110 min when exposed to concentration of $4 \mathrm{gmL}-1$ treatments of alcoholic, aqueous, and acetone extracts, respectively".

\section{CONCLUSION AND RECOMMENDATION}

Several constraint categories with high prevalence were observed on P. biglobosa adult trees. Some constraints pose a serious threat for production, productivity and even the survival of the species. The lack of natural regeneration, in addition to these sanitary constraints, could lead to the extinction of the species in medium and long term if appropriate measures are not taken.

Like other parkland tree species (V. paradoxa for instance), the effect of management practices was found important on
P. biglobosa growth parameters as well as on the prevalence of sanitary constraints. Management practices which include the duration of land use, agricultural activities (reduction of competition, ploughing and fertilization which could benefit to trees) and silvicultural activities (pruning, harvesting) play and important role so that to hide often the effect of climatic factors. Encountered sanitary constraints, influenced by both climatic and anthropic factors, are serious threat for the sustainability of $P$. biglobosa in southern Mali.

So, given this threat, concrete actions are necessary. The most urgent and imperative action would be a general sanitary diagnostic at the level of the distribution area of the species in Mali. Based on the results of this investigation, other activities could be undertaken like:

- Identifying the real cause of damages and seeking for appropriate solutions;

- Sensitizing and training farmers to abandon exploitation of P. biglobosa for wood and to use appropriate trees management technics in parklands;

- Implementing a national program for regeneration of $P$. biglobosa by planting and/or by promoting Assisted Natural Regeneration (ANR) approach where regeneration still exists, so that to renew the aging population in parklands.

All actors involving in the protection, conservation, restoration and sustainable management of natural woody resources (Public powers, Technical services, Research, Peasants, Technical and Financial Partners) are addressed.

\section{ACKNOWLEDGEMENTS}

We are very grateful to the Malian government for funding the Parkia project through the Competitive Fund for Research and Technological Innovation (CFRTI). Many thanks to Somasso, Zanzoni and Diou villages' authorities and populations for allowing to conduct this study on their field and fallow parcels and also for cooperating in field activities. We also thank field technicians (Isaïe Dembélé, Younoussa Diarra and Mamadou Diabaté), which achieved an important work of monitoring and data recording.

\section{REFERENCES}

1. Sina S. Reproduction et diversité génétique chez Parkia biglobosa (Jacq.) G. Don. PhD thesis Wageningen University. 2006; 102 p.

2. Hopkins HC. The taxonomy, reproductive biology and economic potential of Parkia biglobosa (Leguminosae: Mimosoideae) in Africa and Madagascar. Botanical J. Linnean Society. 1983; 87:135-167. 
3. Gutierrez ML. Production et commercialisation de l'afitin fon dans la région d'Abomey-Bohicon au Bénin. CERNA, CNEARC, CIRAD: Etudes et Travaux n 19. 2000;114 p.

4. Odunfa SA. Biochemical changes during "iru" fermentation. Journal of Food Technology. 1985; 20:295-303.

5. Diawara B, Sawadogo L, Amoa Amwa WKA and Jakobsen M. HACCP System for Traditional African Fermented Foods. Soumbala, Taastrup: WAITRO Danish Technological Institute. 1998; ISBN 87-90737-00-8.

6. Ouoba LII, Rechinger KB, Diawara B, Traoré AS and Kakobsen M. Degradation of proteins during the fermentation of African locust bean (Parkia biglobosa) by strains of Bacillus subtilis and Bacillus pumilis for production of Soumbala. Journal of Applied Microbiology. 2003a; 94:396-402

7. Koura K, Mbaide Y. et Ganglo JC. Caractéristiques phénotypique et structurale de la population de Parkia biglobosa (Jacq.) R. Br. du Nord-Bénin. International Journal of Biology and Chemistry Sciences. 2013; 7(6):2409-2425
8. Gutierrez ML et Juhé-Beaulaton D. Histoire du parc à Néré (Parkia biglobosa Jacq. Benth.) sur le plateau d'Abomey (Bénin) : de sa conservation pour la production et la commercialisation d'un condiment, I'afitin. Cahiers d'Outre-Mer, Bordeaux. 2002; 220:453-474.

9. Ademola IT and Oyum MB. Microbial Evaluation of Parkia biglobosa Parts and soils in Savanah Region from Different Provenances in West Africa. Commonwealth Forestry Association. 2016.

10. Encyclopaedia Britannica, Inc. Dieback. URL:https://www.britannica. com/science/dieback. 1998

11. Ojewumi ME, Eluagwule B, Ayoola AA, Ogunbiyi AT, Adeoye J, Eterighoemetere $\mathrm{M}$ and Olufunmilayo OJ. termiticidal effects of african locust bean (Parkia biglobosa biglobosa) seed oil extracts. International Journal of Current Research. 2017; 9(07):53929-53934.

12. Olugbemi B. Termiticidal Activity of Parkia biglobosa (Jacq) Benth Seed Extracts on the Termite Coptotermes intermedius Silvestr (Isoptera: Rhinotermitidae). Hindawi Publishing Corporation. 2012; ID 869415 